\title{
Analisis Pengaruh Motivasi, Pelatihan dan Kepuasan Kerja Terhadap Kinerja Karyawan Pada PT Multi Data Palembang
}

\author{
Agung Indriansyah \\ Universitas Bina Darma \\ Email: agungindriansyah@gmail.com
}

\begin{abstract}
Job satisfaction and job motivation are directly related to staff performance. Job satisfaction and job motivation experienced by staff could reduce or increase staff performace. Staff who feels satisfied with the job obtained will be motivated to increase his/her performace, consequently it will impact on improving the company performance overall. This research was done at the Indonesia based PT Multi Data Palembang. The aim of the research is to investigate the effect of staff performace relation to the job satisfaction and job motivation that has been moderated by job duration. The samples number determined in this research are 30 respondents and used sampling purposive method. As independent variables are job satisfaction and job motivation, and its variable moderating is job duration, while its dependent variable is staff performance. The results of the analysis is using moderated regression are the job Motivation Variable, job Training variable and job satisfaction are positively influenced to staff performance, and the job duration variable moderated job satisfaction to the staff performance, meanwhile job duration variable did not succeed to moderate job motivation to staff performance. The result of the analysis could be known that 22 percent variation of staff performance could be explained by independent variable and moderating variable that has been examined in this research and 78 percent by the other factors outside the model.
\end{abstract}

Keywords: Job motivation, job satisfaction, job training and staff performance

\begin{abstract}
Abstrak
Kepuasan kerja dan motivasi kerja secara langsung berkaitan dengan kinerja staf. Kepuasan kerja dan motivasi kerja yang dialami oleh staf dapat mengurangi atau meningkatkan kinerja staf. Staf yang merasa puas dengan pekerjaan yang diperoleh akan termotivasi untuk meningkatkan kinerjanya, akibatnya akan berdampak pada peningkatan kinerja perusahaan secara keseluruhan. Penelitian ini dilakukan di PT Multi Data Palembang yang berbasis di Indonesia. Tujuan penelitian ini adalah untuk mengetahui pengaruh hubungan kinerja staf terhadap kepuasan kerja dan motivasi kerja yang telah dimoderasi oleh durasi kerja. Jumlah sampel yang ditentukan dalam penelitian ini adalah 30 responden dan menggunakan metode purposive sampling. Sebagai variabel independen adalah kepuasan kerja dan motivasi kerja, dan variabel moderatingnya adalah durasi kerja, sedangkan variabel dependennya adalah kinerja staf. Hasil analisis menggunakan moderated regression adalah variabel Motivasi Kerja, variabel Pelatihan Kerja dan kepuasan kerja berpengaruh positif terhadap kinerja staf, dan variabel durasi kerja memoderasi kepuasan kerja terhadap kinerja staf, sedangkan variabel durasi pekerjaan tidak berhasil memoderasi pekerjaan. motivasi untuk kinerja staf. Hasil analisis dapat diketahui bahwa 22 persen variasi kinerja staf dapat dijelaskan oleh variabel independen dan variabel moderasi yang telah diteliti dalam penelitian ini dan 78 persen oleh faktor - faktor lain diluar model.
\end{abstract}

Kata kunci: Motivasi kerja, kepuasan kerja, pelatihan kerja dan kinerja staf.

\section{Pendahuluan}

Sumber daya manusia dalam hal ini tenaga kerja berperan dalam perusahaan, sehingga dibutuhkan tenaga kerja yang terdidik dan siap pakai untuk mendukung pengembangan perusahaan. Di Kota Palembang terdapat beberapa perusahaan yang bergerak dibidang IT yang bersaing secara ketat. PT. Multi Data Palembang merupakan salah satu Perusahaan "lokal" yang ada di Kota Palembang. Di sisi lain, perusahaan juga harus menjalankan fungsi sosial secara internal dan eksternal untuk menjamin kesejahteraan para anggotanya juga berdampak pada kelangsungan hidup perusahaan. Untuk dapat bersaing dengan industri yang sejenis lainnya, perusahaan harus mempunyai 
keunggulan kompetitif yang sangat sulit ditiru,yang hanya akan diperoleh dari karyawan yang produktif, inovatif, kreatif selalu bersemangat dan loyal. Karyawan yang memenuhi kriteria seperti itu hanya akan dimiliki melalui penerapan konsep dan teknik manajemen sumber daya manusia yang tepat dengan semangat kerja yang tinggi serta pemimpin yang efektif dan lingkungan kerja yang mendukung. Faktor-faktor yang dapat digunakan untuk meningkatkan kinerja pegawai, diantaranya motivasi, pelatihan dan kepuasan kerja, Robbins (2001)

Setiap kegiatan yang dilakukan oleh seseorang didorong oleh suatu kekuasaan dalam diri orang tersebut,kekuatan pendorong inilah yang disebut motivasi. Motivasi kerja karyawan dalam suatu organisasi dapat dianggap sederhana dan dapat pula menjadi masalah yang kompleks, karena pada dasarnya manusia mudah untuk dimotivasi dengan memberikan apa yang menjadi keinginannya. Masalah motivasi kerja dapat menjadi sulit dalam menentukan imbalan dimana apa yang dianggap penting bagi seseorang karena sesuatu yang penting bagi seseorang belum tentu penting bagi orang lain.

Bila seseorang termotivasi, ia akan berusaha berbuat sekuat tenaga untuk mewujudkan apa yang diinginkannya. Namun belum tentu upaya yang keras itu akan menghasilkan produktivitas yang diharapkan, apabila tidak disalurkan dalam arah yang dikehendaki organisasi.

Unsur kebutuhan berarti suatu keadaan internal yang menyebabkan hasil- hasil tertentu tampak menarik. Suatu kebutuhan yang tidak terpuaskan akan menciptakan tegangan yang merangsang dorongan-dorongan di dalam diri individu. Dorongan ini menimbulkan suatu perilaku pencarian untuk menemukan tujuan-tujuan tertentu yang apabila tercapaiakan memenuhi kebutuhanitu dan mendorong ke pengurangan tegangan.

Menurut Luthans(2006) motivasi adalah proses sebagai langkah awal seseorang melakukan tindakan akibat kekurangan secara fisik dan psikis atau dengan kata lain adalah suatu dorongan yang ditunjukan untuk memenuhi tujuan tertentu.Apabila nilai ini tidak terjadi, maka akan terwakili individu-individu yang mengeluarkan tingkat biaya tinggi, yang sebenarnya berlawanan dengan kepentingan organisasi. Rendahnya kinerja karyawan dan motivasi karyawan yang dihadapi sebenarnya merupakan permasalahan klasik namun selalu update untuk didiskusikan.

Penelitian yang dilakukan oleh Listianto dan Setiaji (2007) menyatakan bahwa motivasi kerja berpengaruh positif dan signifikan terhadap kinerja karyawan. Selain itu juga penelitian yang dilakukan oleh Prasetyo dan Wahyuddin (2003) mendukung penelitian sebelumnya yang menyatakan bahwa motivasi berpengaruh positif dan signifikan terhadap kinerja karyawan, dan dalam penelitian ini juga menyatakan motivasi merupakan faktor dominan yang mempengaruhi kinerja karyawan. Daripenelitian terdahulu, hubungan antara motivasi dan kinerja berbanding lurus, artinya bahwa semakin tinggi motivasi karyawan dalambekerja maka kinerja yang dihasilkan juga tinggi.

Salah satu faktor yang mempengaruhi loyalitas karyawan adalah kepuasan kerja karyawan. Kepuasan kerja (jobsatisfaction) adalah keadaan emosional karyawan yang terjadi maupun tidak terjadi titik temu antara nilai balas jasa kerja karyawan dan 
perusahaan atau organisasi dengan tingkat nilai balas jasa yang memang diinginkan oleh karyawan yang bersangkutan.

Dalam hal kepuasan kerja, Gilmer (1966) dalam As'ad (2003) menyebutkan faktor-faktor yang mempengaruhi kepuasan kerja adalah kesempatan untuk maju, keamanan kerja, gaji, perusahaan dan manajemen, faktor intrinsik dan pekerjaan, kondisi kerja, aspek sosial dalam pekerjaan, komunikasi, dan fasilitas.

Sementara itu, menurut Ranu pandojo dan Husnan (2002) mengemukakan beberapa faktor mengenai kebutuhan dan keingianan karyawan, yakni gaji yang baik, pekerjaan yang aman, rekan sekerja yang kompak, penghargaan terhadap pekerjaan, pekerjaan yang berarti, kesempatan untuk maju, pimpinan yang adil dan bijaksana, pengarahan dan perintah yang wajar, dan organisasi atau tempat kerja yang dihargai oleh masyarakat.

Kepuasan kerja atau ketidakpuasan karyawan tergantung pada perbedaan antara apa yang diharapkan. Sebaliknya, apabila yang didapat karyawan lebih rendah daripada yang diharapkan akan menyebabkan karyawan tidak puas. Faktor-faktor yang mempengaruhi kepuasan atau ketidakpuasan kerjayaitu:jenis pekerjaan, rekan kerja, tunjangan, perilaku yang adil, keamanan kerja, peluang menyumbang gagasan, gaji/upah, pengakuan kinerja, dan kesempatan bertumbuh.

Menurut Robbins kepuasan kerja merupakan sikap secara umum yang lebih diwarnai oleh perasaan terhadap situasi dan lingkungan kerja serta merupakan pencerminan dari kepuasan seorang karyawan terhadap kondisi yang berkaitan dengan pelaksanaan pekerjaan. Handoko (1996) berpendapat bahwa kepuasan kerja mempunyai hubungan dengan umur. Ia menyebutkan bahwa semakin tua umur karyawan, mereka cenderung lebih terpuaskan dengan pekerjaan-pekerjaan mereka. Pengharapan-pengharapan yang lebih rendah dan penyesuaian yang lebih baik terhadap situasi kerja karena mereka lebih berpengalaman, menjadi alasan yang melatar belakangi kepuasan kerja mereka.

Kepuasan kerja karyawan pada dasarnya sangat individualisdan merupakan hal yang sangat tergantung pada pribadi masing-masing karyawan. Namun demikian terdapat beberapa faktor yang berhubungan dengan kepuasan kerja karyawan dalam rangka peningkatan kinerja adalah: (a) faktor pekerjaan itu sendiri, merupakan faktor yang berhubungan dengan tingkat dimana pekerjaan menyediakan tugas yang menyenangkan, kesempatan belajar dan kesempatan untuk mendapatkan tanggung jawab. (b) faktor gaji, merupakan faktor yang berhubungan dengan tingkat dimanasejauh mana gaji memenuhi harapan-harapan tenaga kerja, dan bagaimana gaji diberikan. (c) faktor kesempatan atau promosi, merupakan faktor yang berhubungan dengan kesempatankaryawan untuk mengembangkan diri dan memperluas pengalaman kerja, dengan terbukanya kesempatan untuk kenaikan jabatan. (d) faktor supervisor, merupakan faktor yang berhubungan dengan kemampuan supervisor untuk menyediakan bantuan teknis dan perilaku dukungan. (e) faktor rekan kerja, merupakan faktor yang berhubungan dengan kebutuhan dasar manusia untuk melakukan hubungan sosial; akan terpenuhi dengan adanya rekan kerja yang mendukung karyawan.

Ketidakpuasan karyawan dapat terjadi apabila pekerjaanyang dilakukan tidak sesuai dengan apa yang diperoleh dari perusahaan. Ketidakpuasan para karyawan ini 
menimbulkan hal-hal yang tidak diinginkan dan dapat merugikan perusahaan yang bersangkutan. Misalnya; adanya aksimogok kerja, kemangkiran karyawan meningkat, turunnya kinerja karyawan, dan lain-lain. Yang pada akhirnya akan menurunkan kinerja perusahaan itu sendiri. Maka, para pimpinan sebaiknya mengerti apa yang dibutuhkan para karyawan dan mengetahui keinginan-keinginanapa yang membuat karyawan puas dan meningkatkan kinerjanya, berikut semua konsekuensinya, termasuk apa dan berapa bonus yang akan mereka terima jika target atau tujuan kerjanya tercapai. Sehingga para karyawan tidak melakukan hal-hal yang tidak sepantasnya dikerjakan. Kepuasan dan ketidakpuasan yang dirasakan oleh karyawan dapat dilihat dari banyaknya jumlah absensi dan jumlah karyawanyang keluar dan masuk yang terjadi di perusahaan tersebut. Semakin tinggi jumlah karyawan yang keluar diperusahaan, maka tingkat kepuasan karyawan dalam bekerja rendah, karena karyawan merasa tidak cocok bekerja di perusahaan. Tingginya jumlah karyawan yang keluar di perusahaan juga dapat disebabkan oleh kebijakan perusahaan untuk mengurangi jumlah karyawan sehingga dapat terjadi efisiensi dalam proses produksi.

Masa kerja juga merupakan komponen yang paling penting dalam menjelaskan tingkat pengunduran diri karyawan (Robbins, 2006). Semakin lama karyawan bekerja dalam suatu perusahaan semakin kecil kemungkinan karyawan tersebut akan mengundurkan diri. Bukti juga menunjukkan bahwa masa kerja pekerjaan terdahulu dari seorang karyawan merupakan indikator perkiraan yang ampuh atas pengunduran diri karyawan dimasa mendatang (Robbins, 2006).

Berdasarkan latar belakang dan hasil pengamatan sementara dapat diuraikan beberapa masalah antara lain sebagai berikut: (1) Profesionalisme pegawai pada PT Multi Data Palembang belum berjalan secara optimal; (2) Kinerja Pegawai yang efektif dan efisien pada PT Multi Data Palembang belum tercapai secara maksimal; (3) Pendidikan dan pelatihan yang diikuti pegawai PT Multi Data Palembang masih belum optimal mendukung kinerja pegawai; (4) Kurangnya pengawasan dari pihak pimpinan terhadap pegawai yang melanggar aturan-aturan yang telah dibuat; (5) Tidak adanya sangsi yang diberikan pihak pimpinan kepada pegawai yang melakukan kesalahan dan penyimpangan dalam wewenang tugasnya.

\section{Literature Review}

Menurut Terry dan Rue dalam Suharto dan Budi Cahyono (2005) mengatakan bahwa motivasi adalah "...getting a person to exert a high degree of effort..." yang artinya adalah "motivasi membuat seseorang untuk bekerja lebih berprestasi". Menurut Luthans (2006) motivasi adalah proses sebagai langkah awal seseorang melakukan tindakan akibat kekurangan secara fisik dan psikis atau dengan kata lain adalah suatu dorongan yang ditunjukan untuk memenuhi tujuan tertentu. Menurut Gibson dalam Suharto dan Budi Cahyono (2005) teori motivasi terdiri dari, pertama content theories atau teori kepuasan yang memusatkan perhatian pada faktor-faktor dalam diri orang yang menguatkan, megarahkan, mendukung dan menghentikan perilaku. Kedua adalah process theory atau teori proses yaitu menguraikan dan menganalisis bagaimana perilaku itu dikuatkan, diarahkan, didukung, dan dihentikan. Kedua kategori tersebut mempunyai pengaruh penting bagi para manajer untuk memotivasi karyawan. 
Menurut Luthans (2006) motivasi adalah proses sebagai langkah awal seseorang melakukan tindakan akibat kekurangan secara fisik dan psikis atau dengan kata lain adalah suatu dorongan yang ditunjukan untuk memenuhi tujuan tertentu. Indikator yang digunakan untuk mengukur variabel motivasi adalah persepsi mengenai adanya tantangan pekerjaan, persepsi mengenai kemampuan karyawan untuk mengatasi kesukaran, dan persepsi mengenai motif berdasarkan uang.

Menurut Mathis (2002), Pelatihan adalah suatu proses dimana orang - orang mencapai kemampuan tertentu untuk membantu mencapai tujuan organisasi.oleh karena itu, proses ini terikat dengan berbagai tujuan organisasi, pelatihan dapat dipandang secara sempit maupun luas. Secara terbatas, pelatihan menyediakan para pegawai dengan pengetahuan yang spesifik dan dapat diketahui serta keterampilan yang digunakan dalam pekerjaan mereka saat ini. Terkadang ada batasan yang ditarik antara pelatihan dengan pengembangan, dengan pengembangan yang bersifat lebih luas dalam cakupan serta memfokuskan pada individu untuk mencapai kemampuan baru yang berguna baik bagi pekerjaannya saat ini maupun di masa mendatang.

Menurut Luthans (2006), kepuasan kerja adalah hasil dari persepsi karyawan mengenai seberapa baik pekerjaan mereka memberikan hal yang dinilai penting. Indikator yang digunakan dalam pengukuran variabel kepuasan kerja adalah pekerjaan itu sendiri, gaji, kesempatan atau promosi, supervisor dan rekan sekerja. Menurut Moh As'ad (2003), kinerja adalah hasil yang dicapai seseorang menurut ukuran yang berlaku untuk pekerjaan yang bersangkutan. Indikator yang digunakan dalam penelitian ini adalah kualitas, kuantitas, ketepatan waktu, keterampilan dan tingkat pengetahuan karyawan, dan standar profesional kerja.

Locke dalam Luthans (2006) memberikan definisi komprehensif dari kepuasan kerja yang meliputi reaksi atau sikap kognitif, afektif, dan evaluatif dan menyatakan bahwa kepuasan kerja adalah "keadaan emosi yang senang atau emosi positif yang berasal dari penilaian pekerjaan atau pengalaman kerja seseorang." Kepuasan kerja adalah hasil dari persepsi karyawan mengenai seberapa baik pekerjaan mereka memberikan hal yang dinilai penting. Secara umum, kepuasan kerja adalah sikap yang paling penting dan sering dipelajari. Menurut Simamora (1995), kinerja karyawan adalah tingkat terhadap mana para karyawan mencapai persyaratan-persyaratan pekerjaan. Menurut Byars dan Rue (dalam Prasetyo Utomo, 2006), kinerja merupakan derajat penyusunan tugas yang mengatur pekerjaan seseorang. Jadi, Kinerja adalah kesediaan seseorang atau kelompok orang untuk melakukan kegiatan atau menyempurnakannya sesuai dengan tanggung jawabnya dengan hasil seperti yang diharapkan.

\section{Metodologi Penelitian}

Variabel penelitian adalah hal-hal yang dapat membedakan atau membawa variasi pada nilai (Sekaran, 2006). Penelitian ini menguji dua variabel yaitu variabel independen (X) dan varibel dependen (Y). Variabelin dependen dalam penelitian ini adalah adalah motivasi $\left(\mathrm{X}_{1}\right)$, Pelatihan $\left(\mathrm{X}_{2}\right)$ dan kepuasan kerja $\left(\mathrm{X}_{3}\right)$, sedangkan variabel dependen adalah kinerja karyawan (Y).

Definisi operasional adalah operasionalisasi konsep agar dapat diteliti atau diukur melalui gejala-gejala yang ada. Definisi operasional yang digunakan untuk penelitian ini 
kemudian diuraikan menjadi indikator empiris yang meliputi: (1) Motivasi; (2) Pelatihan Kerja; (3) Kepuasan Kerja; (4) Kinerja Karyawan; (5) Lama Kerja.

Pada kasus di atas, untuk mengetahui keeratan hubungan antara motivasi, kemampuan dengan kinerja pegawai digunakan besaran yang akan dianalisis adalah korelasi (r). korelasi adalah salah satu teknik statistik yang digunakan untuk mencari hubungan antara dua variabel atau lebih. Dalam hal ini tidak ditentukan variabel mana yang mempengaruhi variabel yang lainnya.

Nilai koefisien berkisarantara -1 dan 1. Semakin mendekati satu nilai absolute koefisien korelasi maka hubungan antara variabel tersebut semakin kuat sedangkan semakin kecil (mendekati nol) nilai absolute koefisien korelasi maka hubungan antara variabel tersebut semakin lemah. Tanda positif atau negatif menunjukkan arah hubungan.

Untuk mengambil seberapa jauh variabel bebas dapat menjelaskan variabel terikat maka perlu diketahui nilai koefisien determinasi atau penentuan $\mathrm{R}^{2}$. Nilai $\mathrm{R}^{2}$ ini berkisar antara 0 - 1, semakin mendekati 1 nilai $\mathrm{R}^{2}$ tersebut berarti semakin besar variabel independen (X) mampu menerangkan variabel dependent (Y). analisis terhadap nilai $\mathrm{R}$-square $\left(\mathrm{R}^{2}\right)$ ini digunakan untuk mengetahui sejauh mana variabel bebas $\left(\mathrm{X}_{1}, \mathrm{X}_{2}\right.$, dan $\left.\mathrm{X}_{3}\right)$ dapat menerangkan hubungan perubahan variabel terikat (Y). sifat-sifat R-square sangat dipengaruhi oleh banyak variabel bebas dimana semakin banyak variabel bebas semakin besar nilai R-square.

\section{Hasil dan Pembahasan}

Dari tabel menunjukkan bahwa koefisien regresi untuk variabel Motivasi Kerja $\left(\mathrm{X}_{1}\right)$ adalah sebesar 0,460 Pelatihan $\left(\mathrm{X}_{2}\right)$ adalah sebesar 0,444, dan Kepuasan Kerja $\left(\mathrm{X}_{3}\right)$ adalah sebesar 0,379 serta juga menghasilkan nilai konstanta sebesar 1,105.

\section{Coefficients $^{\mathbf{a}}$}

\begin{tabular}{|c|c|c|c|c|c|}
\hline \multirow[b]{2}{*}{ Model } & \multicolumn{2}{|c|}{$\begin{array}{c}\text { Unstandardized } \\
\text { Coefficients } \\
\end{array}$} & \multirow{2}{*}{\begin{tabular}{|c|}
$\begin{array}{c}\text { Standardized } \\
\text { Coefficients }\end{array}$ \\
Beta \\
\end{tabular}} & \multirow[b]{2}{*}{$\mathrm{T}$} & \multirow[b]{2}{*}{ Sig. } \\
\hline & B & Std. Error & & & \\
\hline (Constant) & 1.105 & 1.503 & & .736 & .469 \\
\hline Motivasi Kerja & .460 & .077 & .396 & 5.962 & .000 \\
\hline Pelatihan & .444 & .073 & .343 & 6.043 & .000 \\
\hline Kepuasan Kerja & .379 & .099 & .272 & 3.815 & .001 \\
\hline
\end{tabular}

a. Dependent Variable: Kinerja Karyawan

Sumber : Data diolah peneliti dengan program SPSS

Sehingga persamaan regresi berganda penelitian ini adalah sebagai berikut:

$\mathrm{Y}=1.105+0,460 \mathrm{X}_{1}+0,444 \mathrm{X}_{2}+0,379 \mathrm{X}_{3}+\mathrm{e}$

Hasil perhitungan tersebut dapat diinterpretasikan sebagai berikut:

a. Konstanta sebesar 1,105 menyatakan bahwa jika tidak ada peningkatan Motivasi Kerja $\left(\mathrm{X}_{1}\right)$, Pelatihan $\left(\mathrm{X}_{2}\right)$ dan Kepuasan Kerja $\left(\mathrm{X}_{3}\right)$, maka Kinerja Karyawan tetap 
sebesar 1,105 unit skor. Hal ini dapat diterima, karena masih banyak variabel lain yang belum dimasukkan dalam penelitian ini seperti Manajemen Organisasi, Disiplin Kerja dan lainnya.

b. Dengan melihat besarnya koefisien regresi bahwa variabel Motivasi Kerja ( $\left.X_{1}\right) 0,460$ atau sama dengan $46 \%$ Artinya kecenderungan proyeksi perubahan antara variabel Motivasi Kerja $\left(\mathrm{X}_{1}\right)$ dengan variabel Kinerja Karyawan (Y) menunjukkan bahwa setiap perubahan atau peningkatan variabel Motivasi Kerja $\left(\mathrm{X}_{1}\right)$ sebesar $100 \%$ maka akan meningkatkan pula pada variabel Kinerja Karyawan sebesar 46\%.

c. Dengan melihat besarnya koefisien regresi bahwa variabel Pelatihan $\left(\mathrm{X}_{2}\right)$ 0,444 atau sama dengan 44,4\%. Artinya kecenderungan proyeksi perubahan antara variabel Pelatihan $\left(\mathrm{X}_{2}\right)$ dengan variabel Kinerja Karyawan (Y) menunjukkan bahwa setiap perubahan atau peningkatan variabel Pelatihan $\left(\mathrm{X}_{2}\right)$ sebesar $100 \%$ maka akan meningkatkan perubahan atau peningkatan pula pada variabel Kinerja Karyawan sebesar $44,4 \%$.

d. Dengan melihat besarnya koefisien regresi bahwa variabel Kepuasan Kerja ( $\left.X_{3}\right)$ 0,379 atau sama dengan $37,9 \%$. Artinya kecenderungan proyeksi perubahan antara variabel Kepuasan Kerja $\left(\mathrm{X}_{3}\right)$ dengan variabel Kinerja Karyawan $(\mathrm{Y})$ menunjukkan bahwa setiap perubahan atau peningkatan variabel Kepuasan Kerja $\left(\mathrm{X}_{3}\right)$ sebesar $100 \%$ maka akan meningkatkan perubahan atau peningkatan pula pada variabel Kinerja Karyawan sebesar $37,9 \%$

Analisis korelasi digunakan untuk mengetahui hubungan antara variabel motivasi kerja $\left(\mathrm{X}_{1}\right)$, pelatihan $\left(\mathrm{X}_{2}\right)$, dan kepuasan kerja $\left(\mathrm{X}_{3}\right)$ dengan kinerja karyawan $(\mathrm{Y})$, yang dapat dilihat pada tabel korelasi. Dari tabel dibawah terlihat bahwa nilai-nilai koefisien korelasi tersebut ternyata terdapat hubungan yang positif atau signifikan. Berdasarkan tabel diatas juga dapat diketahui bahwa hubungan antara variabel Independen yang meliputi Motivasi Kerja $\left(\mathrm{X}_{1}\right)$, Pelatihan $\left(\mathrm{X}_{2}\right)$ dan Kepuasan Kerja $\left(\mathrm{X}_{3}\right)$ dengan variabel Dependen yaitu variabel Kinerja Karyawan lebih besar dari 0,5 dimana ini berarti bahwa ada hubungan yang kuat antar Variabel Motivasi Kerja, Pelatihan dan Kepuasan Kerja dengan Variabel Kinerja Karyawan

Sedangkan untuk tingkat signifikansinya terlihat bahwa masing-masing variabel yang terdiri dari variabel Independen yang meliputi Motivasi Kerja $\left(\mathrm{X}_{1}\right)$, Pelatihan $\left(\mathrm{X}_{2}\right)$ dan Kepuasan Kerja $\left(\mathrm{X}_{3}\right)$ dengan Variabel Dependen yang meliputi Variabel Kinerja Karyawan (Y) mempunyai nilai yang lebih kecil dari 0,05. Yang mana ini berarti bahwa terdapat hubungan yang erat antara variabel $\mathrm{X}$ dan $\mathrm{Y}$.

Sehingga dapat disimpulkan bahwa adanya hubungan yang positif kuat serta erat antara variabel Independen dan variabel Dependen.

\section{Korelasi}




\begin{tabular}{|c|c|c|c|c|c|}
\hline & & $\begin{array}{l}\text { Motivasi } \\
\text { Kerja }\end{array}$ & Pelatihan & $\begin{array}{l}\text { Kepuasan } \\
\text { Kerja }\end{array}$ & \begin{tabular}{|l} 
Kinerja \\
Karyawan
\end{tabular} \\
\hline \multirow[t]{3}{*}{$\begin{array}{l}\text { Motivasi } \\
\text { Kerja }\end{array}$} & $\begin{array}{l}\text { Pearson } \\
\text { Correlation }\end{array}$ & 1 & $.947^{* *}$ & $.967^{* *}$ & $.984^{* *}$ \\
\hline & Sig. (2-tailed) & & .000 & .000 & .000 \\
\hline & $\mathrm{N}$ & 30 & 30 & 30 & 30 \\
\hline \multirow[t]{3}{*}{ Pelatihan } & $\begin{array}{l}\text { Pearson } \\
\text { Correlation }\end{array}$ & $.947^{* *}$ & 1 & $.954^{* *}$ & $.978^{* *}$ \\
\hline & Sig. (2-tailed) & .000 & & .000 & .000 \\
\hline & $\mathrm{N}$ & 30 & 30 & 30 & 30 \\
\hline \multirow[t]{3}{*}{$\begin{array}{l}\text { Kepuasan } \\
\text { Kerja }\end{array}$} & $\begin{array}{l}\text { Pearson } \\
\text { Correlation }\end{array}$ & $.967^{* *}$ & $.954^{* * *}$ & 1 & $.983^{* *}$ \\
\hline & Sig. (2-tailed) & .000 & .000 & & .000 \\
\hline & $\mathrm{N}$ & 30 & 30 & 30 & 30 \\
\hline \multirow[t]{3}{*}{$\begin{array}{l}\text { Kinerja } \\
\text { Karyawan }\end{array}$} & $\begin{array}{l}\text { Pearson } \\
\text { Correlation }\end{array}$ & $.984^{* *}$ & $.978^{* *}$ & $.983^{* *}$ & 1 \\
\hline & Sig. (2-tailed) & .000 & .000 & .000 & \\
\hline & $\mathrm{N}$ & 30 & 30 & 30 & 30 \\
\hline
\end{tabular}

Sumber : Data diolah peneliti dengan program SPSS

Analisis ini digunakan untuk mengukur berapa bagian dari total keragaman dalam variabel Dependen (Y) yang dapat dijelaskan oleh beragamnya nilai-nilai yang diberikaan setiap variabel Independen (X). Besarnya nilai Koefisien determinasi dapat dilihat pada tabel 4.26 dibawah ini:

\section{Koefisien Korelasi dan Koefisien determinasi}

\begin{tabular}{|l|r|r|r|r|}
\hline Model & \multicolumn{1}{|c|}{$\mathrm{R}$} & R Square & $\begin{array}{c}\text { Adjusted R } \\
\text { Square }\end{array}$ & $\begin{array}{l}\text { Std. Error of } \\
\text { the Estimate }\end{array}$ \\
\hline 1 & $.997^{\mathrm{a}}$ & .993 & .993 & .671 \\
\hline
\end{tabular}

a. Predictors: (Constant), Motivasi Kerja, Pelatihan, Kepuasan Kerja

Sumber: Pengolahan data SPSS.

Dari Tabel di atas dapat ditentukan sebagai berikut:

a. Koefisien korelasi (R) sebesar 0,997 yang berarti hubungan antara Variabel Motivasi Kerja $\left(\mathrm{X}_{1}\right)$, Pelatihan $\left(\mathrm{X}_{2}\right)$ dan Kepuasan Kerja $\left(\mathrm{X}_{3}\right)$ dengan Kinerja Karyawan $(\mathrm{Y})$ adalah $99,7 \%$

b. Koefisien determinasi (R Square) didapat dari koefisien regresi $\left(\mathrm{R}^{2}\right)$ sebesar 0,993 yang berarti $99,3 \%$ proporsi variasi variabel Motivasi Kerja $\left(X_{1}\right)$, Pelatihan $\left(X_{2}\right)$ dan Kepuasan Kerja $\left(\mathrm{X}_{3}\right)$ dengan Kinerja Karyawan terhadap variasi variabel Kinerja Karyawan sisanya $(100 \%-99,3 \%=0,7 \%)$ dipengaruhi oleh variabel diluar dari variabelMotivasi Kerja $\left(\mathrm{X}_{1}\right)$, Pelatihan $\left(\mathrm{X}_{2}\right)$ dan Kepuasan Kerja $\left(\mathrm{X}_{3}\right)$ yang tidak dijelaskan di dalam penelitian ini. 
Untuk melihat hasil pengujian terhadap Hipotesis yang diajukan dapat dilihat pada tabel Coefisien dan pada tabel Anova dimana pada penelitian ini hipotesis yang akan diuji secara statistik dalam penelitian ini adalah :

Berdasarkan data pada tabel di bawah ini terlihat jika Nilai F hitung sebesar 1280.550 dengan tingkat signifikansi sebesar 0,00 dan nilainya masih di bawah nilai $\alpha$ sebesar $5 \%$ $(\alpha=0,05)$.Sehingga dapat disimpulkan jika $\mathrm{H}_{0}$ ditolak dan terdapat pengaruh gaya Motivasi Kerja, Pelatihan dan Kepuasan Kerja terhadap kinerja karyawan.

\section{ANOVA ${ }^{b}$}

\begin{tabular}{|c|c|c|c|c|c|c|}
\hline \multicolumn{2}{|c|}{ Model } & $\begin{array}{l}\text { Sum of } \\
\text { Squares }\end{array}$ & Df & Mean Square & $\mathrm{F}$ & Sig. \\
\hline \multirow[t]{3}{*}{1} & Regression & 1728.171 & 3 & 576.057 & 1280.550 & $.000^{\mathrm{a}}$ \\
\hline & Residual & 11.696 & 26 & .450 & & \\
\hline & Total & 1739.867 & 29 & & & \\
\hline
\end{tabular}

a. Predictors: (Constant), Motivasi Kerja, Pelatihan, Kepuasan Kerja

b. Dependent Variable: Kinerja Karyawan

Sumber: Pengolahan data SPSS

Bahwa antara variabel Motivasi Kerja $\left(\mathrm{X}_{1}\right)$ mempunyai hubungan yang signifikan terhadap variabel Kinerja Karyawan (Y) dengan nilai korelasi sebesar 0,984 termasuk pada katagori tingkat hubungan yang kuat, erat dan positif serta signifikan, kerena setelah dikonsultasikan dengan nilai (r) pada tabel kritik (r) product moment, nilai (r) hitung lebih besar dari (r) tabel.Bahwa antara variabel Pelatihan $\left(\mathrm{X}_{2}\right)$ mempunyai hubungan yang signifikan terhadap variabel Kinerja Karyawan (Y) dengan nilai korelasi sebesar 0,978 termasuk pada katagori tingkat hubungan yang kuat, erat dan positif serta signifikan, kerena setelah dikonsultasikan dengan nilai (r) pada tabel kritik (r) product moment, nilai (r) hitung lebih besar dari (r) tabel.Bahwa antara variabel Kepuasan Kerja $\left(\mathrm{X}_{3}\right)$ mempunyai hubungan yang signifikan terhadap variabel Kinerja Karyawan (Y) dengan nilai korelasi sebesar 0,983 termasuk pada katagori tingkat hubungan yang kuat, erat dan positif serta signifikan, kerena setelah dikonsultasikan dengan nilai (r) pada tabel kritik (r) product moment, nilai (r) hitung lebih besar dari (r) tabel.

Bahwa antara variabel Motivasi Kerja $\left(\mathrm{X}_{1}\right)$, Pelatihan $\left(\mathrm{X}_{2}\right)$ dan Kepuasan Kerja $\left(\mathrm{X}_{3}\right)$ mempunyai hubungan yang signifikan terhadap variabel Kinerja Karyawan (Y) dengan nilai Koefisien Korelasi (R) sebesar 0,997 termasuk pada katagori tingkat hubungan yang kuat, erat dan positif serta signifikan.Koefisien determinasi (R Square) didapat dari koefisien regresi $\left(\mathrm{R}^{2}\right)$ sebesar 0,993 yang berarti 99,3\% proporsi variasi variabel Variabel Motivasi Kerja $\left(\mathrm{X}_{1}\right)$, Pelatihan $\left(\mathrm{X}_{2}\right)$ dan Kepuasan Kerja $\left(\mathrm{X}_{3}\right)$ dengan Kinerja Karyawan terhadap variasi variabel Kinerja Karyawan sisanya $(100 \%-99,3 \%=0,7 \%)$ dipengaruhi oleh variabel diluar dari variabel Motivasi Kerja $\left(\mathrm{X}_{1}\right)$, Pelatihan $\left(\mathrm{X}_{2}\right)$ dan Kepuasan Kerja $\left(\mathrm{X}_{3}\right)$ yang tidak dijelaskan di dalam penelitian ini

\section{Simpulan}


Berdasarkan kesimpulan diatas, maka dapat diimplikasikan Motivasi, Pelatihan dan Kepuasan Kerja secara bersama - sama mempunyai pengaruh signifikan positif terhadap Kinerja Karyawan. Motivasi mempunyai pengaruh yang lebih besar terhadap kinerja karyawan, agar kinerja karyawan menjadi lebih baik yang harus lebih diperhatikan oleh perusahaan adalah bagaimana meningkatkan motivasi kerja karyawan secara maksimal. Hal ini menunjukkan bahwa upaya untuk meningkatkan Kinerja karyawan PT. Multi Data Palembang dapat dilakukan melalui peningkatan Motivasi kerja, Pelatihan kerja dan Kepuasan kerja. Upaya tersebut yang pada gilirannya akan meningkatkan kinerja karyawan pada PT. Multi data Palembang.

Selain faktor Motivasi, Pelatihan dan Kepuasan kerja yang berpengaruh terhadap kinerja, dari analisis regresi terdapat faktor lain yang mempengaruhi Kinerja, maka faktor lain tersebut harus menjadi perhatian pula, guna meningkatkan kinerja karyawan dimasa yang akan datang. Faktor lain sebagaimana disebut diantaranya adalah disiplin kerja, sikap, perilaku dan lain sebagainya. Dari kesimpulan diatas dapat dilihat bahwa tingkat kepuasan kerja karyawan masih rendah di bandingkan variabel lain, maka di sarankan kepada pihak manajemen agar supaya dapat meningkatkan tingkat kepuasan kerja karyawan guna meningkatkan kinerja karyawan dimasa yang akan datang dengan cara memberikan reward penghargaan apresiasi dan bonus - bonus dari hasil usaha dan kinerja karyawan

\section{Daftar Pustaka}

Ferdinand, A. (2006). Metode Penelitian Manajemen Semarang: Badan Penerbit Universitas Diponegoro.

Ma'rifah, D. (2006). Pengaruh Motivasi Kerjadan Budaya Organisasi Terhadap Kinerja Pekerja Sosial pada Unit Pelaksana Teknis Dinas Sosial Propinsi Jawa Timur.

Mas`ud, F. (2004). Survai Diagnosis Organisasional, Konsep \& Aplikasi. Semarang: Badan Penerbit Universitas Diponegoro.

Simamora, H. (1995). Manajemen Sumber Daya Manusia.Yogyakarta: BP STIE YKPN

Ghozali, I. (2006). Aplikasi Analisis Multivariate dengan Program SPSS. Semarang: Badan Penerbit Universitas Diponegoro.

Kreitner, R., \& Kinicki, A. (2005). Perilaku Organisasi. Jakarta: Salemba Empat.

Luthans, F. (2006). Perilaku Organisasi 10th. Edisi Indonesia. Yogyakarta: Penerbit ANDI.

Hasibuan, M.S.P. (2003). Manajemen Sumber Daya Manusia. Yogyakarta: STIE YKPN.

As'ad, M. (2003). Psikologi Industri. Yogyakarta: Libery.

Manullang, M. (1981). Manajemen Personalia. Jakarta: Ghalia Indonesia.

Emilisa, N. (2001). Hubungan Antara Job Satisfaction Dengan Organizational Commitment Pada Dana Pensiun Lembaga Keuangan Yang Dikelola Oleh Perusahaan Asuransi di Jakarta. Jurnal Media Riset Bisnis \& Manajemen, 1(3), pp. $229-244$.

Almigo, N. (2004). Hubungan Antara Kepuasan Kerja dengan Produktivitas Kerja Karyawan. Jurnal PSYCHE, 1(1).

Utomo, P. (2006). Analisis Pengaruh Pemberdayaan Dan Lingkungan Kerja Terhadap Kinerja Karyawan Patra Semarang Convention Hotel.

Purwanto., \& Wahyuddin. (2007). Pengaruh Faktor-faktor Kepuasan Kerja Terhadap 
Kinerja Karyawan Pusat Pendidikan Komputer Akuntansi IMKAdi Surakarta. Solo: Program Pascasarjana Universitas Muhammadiyah Surakarta.

Stephen, S. (1996). Perilaku Organisasi,Konsep, Kontroversi-Aplikasi. Jilid 2 Edisi Bahasa Indonesia. Jakarta: Prenhallindo.

Siagian, S.P. (2001). Manajemen Sumber Daya Manusia, Edisike 1 Cetakan Ketiga. Jakarta: Bima Aksara.

Uma, S. (2006). Metodologi Penelitian Untuk Bisnis Edisi 4, Jakarta: Salemba Empat. Sugiyono. (1999). Metode Penelitian Bisnis. Bandung: Penerbit Alfabeta.

Listianto, T., \& Setiaji, B. (2007). Pengaruh Motivasi, Kepuasan dan Disiplin Kerja Terhadap Kinerja Karyawan (Studi Kasus di Lingkungan Pegawai Kantor PDAM Kota Surakarta).

\section{Copyright Disclaimer}

Copyright for this article is retained by the author(s), with first publication rights granted to the journal. 